\title{
Determining Chemical Composition of Cattle Urine and Indigenous Plant Extracts
}

\author{
M. N. A. Miah" ${ }^{1 *}$ M. R. U. Miah' ${ }^{2}$ and M. Z. Alam² \\ ${ }^{1}$ Bangladesh Sugarcrop Research Institute, Ishurdi-6620, Pabna, Bangladesh \\ ${ }^{2}$ Department of Entomology, Bangabandhu Sheikh Mujibur Rahman Agricultural University, Bangladesh.
}

\section{ABSTRACT}

The study was conducted to determine the specific chemical constituents of cattle urine and indigenous plant extracts. Chemical analysis revealed that the specific chemical composition i.e., chloride, sulphate, nitrite and phosphorus pentaoxide contents of fresh and fermented cattle urine were 1556, 364, 2.0, 26.8 and 4514, 252, 22.4, $7.49 \mathrm{mg} \mathrm{l}^{-1}$, respectively. The proximate chemical compositions of neem seed kernel extracts, mahagoni seed extracts and allamanda leaves extracts were analyzed and it was found to contain chloride $(144,55.4,141$ mg $\left.\mathrm{l}^{-1}\right)$, sulphate $\left(51.1,5.03,<4.0 \mathrm{mg} \mathrm{l}^{-1}\right)$, nitrite $\left(<1.0,<1.0,<1.0 \mathrm{mg} \mathrm{l}^{-1}\right)$ and phosphorus pentaoxide $\left(413,410,49.5 \mathrm{mg} \mathrm{l}^{-1}\right)$, respectively. Chloride and nitrite in fermented cattle urine (4514 and $22.4 \mathrm{mg} \mathrm{l}^{-1}$ ) was found extremely higher than in fresh cattle urine (1556 and $2.0 \mathrm{mg}$ $\left.1^{-1}\right)$. There was numerically higher difference in sulphate and phosphorus pentaoxide concentrations in fresh cattle urine $\left(364,26.8 \mathrm{mg} \mathrm{l}^{-1}\right)$ compared to fermented cattle urine (252, $7.49 \mathrm{mg} \mathrm{l}^{1-1}$. These results revealed that indigenous plant extracts of neem seed kernel, mahagoni seed and allamanda leaves contents chloride, sulphate and nitrite were extremely lower than in both fresh and fermented cattle urine but there were great difference in phosphorus pentaoxide concentration $\left(413,410,49.5 \mathrm{mg} \mathrm{l}^{-1}\right)$ in both fresh and fermented cattle urine $\left(26.8,7.49 \mathrm{mg} \mathrm{l}^{-1}\right)$ composition. It was evident from this study that as the fermented cattle urine contained higher concentration of chloride and nitrite can be considered as a good means of insect pest management.

Keywords: Chemical constituents, Cattle urine, Indigenous plant extracts.

\section{Introduction}

Today the rapid increase in human population and demand of food materials has initiated the large use of insecticides. Because of the application of these toxic chemical insecticides and due to their biomagnifications, the environment is getting polluted making the fertile land infertile. The conventional farming practices

* Corresponding author email: miahnur749@,outlook.com DOI : https://doi.org/10.21467/ias.3.1.23-26 which uses chemical methods to kill both useful and harmful life forms indiscriminately, resulting in the malfunctioning of food chain and web. Bio-control is the best method to cope with the losses done by the chemicals [1]. Chemical insecticides kill the predators and parasitoids. Cypermethrin affected lady bird beetles and spiders population [2]. Inappropriate selection of insecticides and doses, improper spray scheduling and inadequate spray coverage may cause to the failure in controlling insect pests [3]. 
Locally available plant materials have been widely used in the past to protect damage caused by insect infestation. Eco-friendly management of pest such as use of natural products i.e., cattle urine and plant extracts have a great chance to save the beneficial insects. Article [4] Presented a review of current information on the composition, pharmacological actions and mode of death from cattle urine concoction (CUC) toxicity. The CUC poisoning showed that the main effects are severe depression of respiration, cardiovascular system, the central nervous system and hypoglycemia. These toxic effects acting singly or in combination are the cause(s) of death. Neem as having powerful insecticidal properties is considered to be one of the most promising plants of the 21st century for its great potential in pest management and environment protection [5]. The mahagoni seed extracts possess antibacterial and antifungal activities [6]. According to [7] all parts of the allamanda plant contain allamandin, a toxic iridoid lactone. Plants are rich sources of secondary metabolites with interesting biological activities [8].

Researcher [9] shows cattle urine contains nitrogen, sulphur, ammonia, copper, phosphate, sodium, potassium, manganese, carbolic acid, iron, uric acid, urea, silicon, chlorine, magnesium, calcium, lactose, enzymes, creatinine, aurum hydroxide .Total $\mathrm{N}$ in the cattle urine ranged from 6.8 to $21.6 \mathrm{~g} \mathrm{~N}$ litre $^{-1}$, of which an average of $69 \%$ was present as urea, $7.3 \%$ as allantoin, $5.8 \%$ as hippuric acid, $3.7 \%$ as creatinine, $2.5 \%$ as creatine, $1.3 \%$ as uric acid, $0.5 \%$ as xanthine plus hypoxanthine, $1.3 \%$ as free amino acid $\mathrm{N}$ and $2.8 \%$ as ammonia [10]. Researcher [11] found that mahagoni seed contain moisture (14.37\%), minerals $(16.36 \%)$, fats $(19.42 \%)$, crude fiber $(19.60 \%)$, protein $(8.76 \%)$ and carbohydrate $(21.49 \%)$. Allamanda leaves contains moisture 3.0, sulphated 0.008 , acid insoluble 0.0008 , ash 4.0, proteins 6.8, fats 3.0, crude fibre 23.0, carbohydrate 60.0 , Tannin acid 0.215 , oxalate 0.001 and phytate $0.0009(\% \mathrm{w} / \mathrm{w})$ [8].

Natural products are safe to apply, unique in action and can easily be processed. It has little or no effect against beneficial spiders, ladybird beetles, parasitoid, wasps, predatory mites and insects [12]. The products are also cost effective and readily available to the farmers in time. Use of natural product against insect pest control has drawn special attention to the entomologist all over the world. Considerable work on the chemical composition of cattle urine and indigenous plant extracts had been done in many countries in the world. But only a few attempts have been made to evaluate natural products against insect pests in Bangladesh [13]. Therefore, the study was undertaken to determine the specific chemical constituents present in cattle urine and indigenous plant extracts.

\section{Materials and Methods}

The experiment was conducted at Institute of National Analytical Research and Service (INARS) of Bangladesh Council of Scientific and Industrial Research (BCSIR) laboratories, Dhaka, Bangladesh for analysis the constituents of cattle urine and three indigenous plant extracts during the period of 29 October, 2013 to December 14, 2013. The fresh cattle urine was collected from farmer's farm in the morning for analyses. After collection it was kept underground in an earthen pot for 14 days for fermentation. Neem and mahagoni fruits were collected when the fruits turn yellowish-green and were processed as soon as possible. The fleshy part of the seed was removed and the stones were washed in clean water and dried for 5-10 days. Then seeds were crushed and soaked overnight in little quantity of water. Later, the mixture was squeezed through the muslin cloth. Allamanda leaves extracts were collected after blending. The collected samples were kept in plastic bottles at room temperature after labeling properly for laboratory analysis. Chemical analysis was done for fresh cattle urine, fermented cattle urine, neem seed kernel extracts, mahagoni seed extracts and allamanda leaves extracts individually.

\section{Results and Discussion}

The results showed that chloride, sulphate, nitrite and phosphorus pentaoxide contents of fresh cattle urine and fermented cattle urine were 1556, 364, 2.0, 26.8 and 4514, 252, 22.4, $7.49 \mathrm{mg} \mathrm{l}^{-1}$, respectively (Table 1). It is illustrated that 
Miah et al., Int. Ann. Sci.; Vol. 3 Issue 1, pp: 23-26, 2017

chloride and nitrite in fermented cattle urine was extremely higher (4514 and $22.4 \mathrm{mg} \mathrm{l}^{-1}$ ) than that in fresh cattle urine (1556 and $2.0 \mathrm{mg} \mathrm{l}^{-1}$ ). There was numerically more difference in sulphate and phosphorus pentaoxide concentrations in fresh cattle urine $\left(364,26.8 \mathrm{mg} \mathrm{l}^{-1}\right)$ compared to fermented cattle urine $\left(252,7.49 \mathrm{mg} \mathrm{l}^{-1}\right)$.

Table 1: The specific chemical constituents of fresh and fermented cattle urine analyzed by INARS, BCSIR, Dhaka, Bangladesh.

\begin{tabular}{|c|c|c|}
\hline \multirow{2}{*}{$\begin{array}{c}\text { Chemical } \\
\text { constituents }\end{array}$} & \multicolumn{2}{|c|}{ Concentration $\left(\mathrm{mg} \mathrm{l}^{-1}\right)$} \\
\hline & $\begin{array}{l}\text { Fresh } \\
\text { cattle } \\
\text { urine }\end{array}$ & $\begin{array}{l}\text { Fermented } \\
\text { cattle urine }\end{array}$ \\
\hline Chloride $\left(\mathrm{Cl}^{-}\right)$ & 1556 & 4514 \\
\hline Sulphate $\left(\mathrm{SO}_{4}{ }^{2-}\right)$ & 364 & 252 \\
\hline Nitrite $\left(\mathrm{NO}_{2}\right)$ & 2.0 & 22.4 \\
\hline $\begin{array}{l}\text { Phosphorus } \\
\text { Pentaoxide }\left(\mathrm{P}_{2} \mathrm{O}_{5}\right)\end{array}$ & 26.8 & 7.49 \\
\hline
\end{tabular}

It reveals from the Table 2 that chloride, sulphate, nitrite and phosphorus pentaoxide contents of neem seed kernel extracts were 144, 51.1, <1.0, and $413 \mathrm{mg} \mathrm{l}^{-1}$, respectively. It was found that chloride, sulphate and phosphorus pentaoxide in neem seed kernel extracts (144, 51.1 and $413 \mathrm{mg} \mathrm{l}^{-1}$ ) were higher than the others. The highest chloride concentration was obtained from neem seed kernel extract (144 mg $\mathrm{l}^{-1}$ ) whereas the lowest in mahagoni seed extract (55.4 $\mathrm{mg} \mathrm{l}^{-1}$ ). There was numerically higher difference in sulphate concentration in neem seed kernel extract $\left(51.1 \mathrm{mg} \mathrm{l}^{-1}\right)$ compared to extracts of mahagoni and allamanda $(5.03$ and $<4.0 \mathrm{mg} \mathrm{l}$ 1). The results showed that nitrite concentration was same amount in three plant extracts $(<1.0 \mathrm{mg}$ $\left.1^{-1}\right)$. Phosphorus pentaoxide contents of neem seed kernel extract was extremely higher (413 mg $\left.\mathrm{l}^{-1}\right)$ than in allamanda leaves extract $\left(49.5 \mathrm{mg} \mathrm{l}^{-1}\right)$. It was found from the Figure 1 that chloride and nitrite contents in fermented cattle urine were extremely higher (4514 and $22.4 \mathrm{mg} \mathrm{l}^{-1}$ ) than the others. There was numerically higher difference in phosphorus pentaoxide concentration in fresh cattle urine and three plant extract $(26.8,413,410$, $\left.49.5 \mathrm{mg} \mathrm{l}^{-1}\right)$ compared to fermented cattle urine $\left(7.49 \mathrm{mg} \mathrm{l}^{-1}\right)$.

Table 2: The specific chemical constituent of different plant extracts analyzed by INARS, BCSIR, Dhaka, Bangladesh.

\begin{tabular}{|l|c|c|c|}
\hline \multirow{2}{*}{$\begin{array}{l}\text { Chemical } \\
\text { constituents }\end{array}$} & \multicolumn{3}{|c|}{ Concentration $\left(\mathrm{mg} \mathrm{l}^{\mathbf{- 1}}\right)$} \\
\cline { 2 - 4 } & NSKE* & MSE & ALE \\
\hline Chloride $\left(\mathrm{Cl}^{-}\right)$ & 144 & 55.4 & 141 \\
\hline Sulphate $\left(\mathrm{SO}_{4}{ }^{2-}\right)$ & 51.1 & 5.03 & $<4.0$ \\
\hline Nitrite $\left(\mathrm{NO}_{2}\right)$ & $<1.0$ & $<1.0$ & $<1.0$ \\
\hline $\begin{array}{l}\text { Phosphorus } \\
\text { Pentaoxide } \\
\left(\mathrm{P}_{2} \mathrm{O}_{5}\right)\end{array}$ & 413 & 410 & 49.5 \\
\hline
\end{tabular}

* NSKE $=$ Neem seed kernel extract, MSE $=$ Mahagoni seed extract, $\mathrm{ALE}=$ Allamanda leaves extract

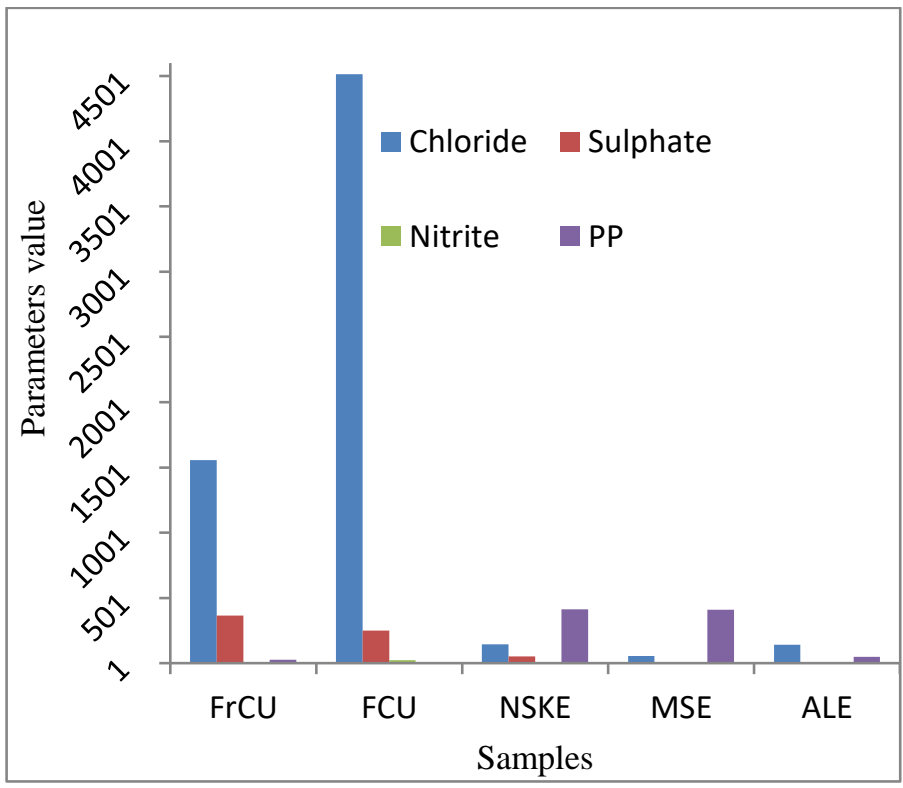

Figure 1: Comparison of chemical constituents of FrCU, FCU, NSKE, MSE and ALE.

$($ FrCU $=$ Fresh cattle urine, FCU $=$ Fermented cattle urine, $\mathrm{NSKE}=$ Neem seed kernel extract, ALE $=$ Allamanda leaves extract)

\section{Conclusion}

From chemical content of view, among all the treatments, fermented cattle urine, fresh cattle urine, neem seed kernel extract, mahagoni seed extract and allamanda leaves extracts the presence of chloride, sulphate and nitrite contents in fermented cattle urine was found 
extremely higher (4514, 252 and $22.4 \mathrm{mg} \mathrm{l}^{-1}$, respectively) than the others. There was numerically higher difference in phosphorus pentaoxide concentration in fresh cattle urine and three plant extract $\left(413,410,49.5\right.$ and $26.8 \mathrm{mg} \mathrm{l}^{-1}$, respectively) compared to fermented cattle urine (7.49 $\mathrm{mg} \mathrm{l}^{-1}$ ). Hence was evident that fermented cattle urine could be considered as a good means of insect pest repellent for their management which is very important for modern agriculture. In addition, it is not only economical and ecologically safe but also free from residual problems.

\section{Acknowledgments}

The authors are grateful to the Entomology laboratory of Bangabandhu Sheikh Mujibur Rahman Agricultural University, Gazipur, Bangladesh to provide all facilities and extending cooperation in conducting the experiment. A special appreciation is also extended to honorable authority of Bangladesh Sugarcrop Research Institute (BSRI) for their kind cooperation and awarded Ph.D. scholarship under "Create Employment Opportunities of Char Dwellers in Greater Rangpur Districts Through Sugarcane Cultivation" funded by Japan Debt Cancellation Fund (JDCF) throughout the study.

\section{How to Cite this Article:}

M. Miah, M. R. Miah and M. Alam, "Determining Chemical Composition of Cattle Urine and Indigenous Plant Extracts" International Annals of Science, vol. 3, no. 1, pp. 23-26, Dec 2017. doi: https://doi.org/10.21467/ias.3.1.23-26

\section{References}

Mansinghka, S.S. "Bi-products of cattle-organic manure and Cow urine-Medicines-Draught-GasElectricity" Explanatory note of Justice Guman Mal Lodha. Chapter V-Part1, India, 2007.

[2] Maleque, M.A., Maeto, K., Ishii, H.T. Arthropods as bio-indicators of sustainable forest management, with a focus on plantation forests. Appl. Entomol. Zool., vol. 44, pp. 1-11, 2009.

[3] Phillips, J.R., Graves, J.P., Luttrell. Insecticide resistance management: relationships to integrated pest management. Pesticide Sci., vol. 27, pp. 459-467, 1990.

[4] Oyebola, D.D. Cows urine concoction: its chemical composition, pharmacological actions and mode of lethality. African Journal Medical Science., vol. 12, pp. $57-63,1983$.

[5] WHO (World Health Organisation): Global strategic framework for integrated vector management. Switzerland, Geneva, 1989.

[6] Majid, M.A., Rahman, I.M.M., Shipar, M.A.H., Uddin, M.H., Chowdhury, R. Physico chemical characterization, antimicrobial activity and toxicity analysis of S. mahagoni seed oil. Int. J. Ari. Biol., vol.6, pp. 350-354, 2004.

[7] Uduak A. E., Esther S. U. Comparative phytochemical screening and nutritional potentials of the stems, leaves and flowers of Allamanda cathartica (Apocynaceae). International Journal of Science and Technology., vol. 4, no.6, pp. 248-253, 2015.

[8] Fatima, A., Modolo, L.V., Conegero, L.S., Pilli, R.A., Ferreira, C.V., Kohn, L.K. Lactones and their derivatives: biological activities, mechanisms of action and potential leads for drug design. Curr Med Chem., vol. 13, pp. 3371-3384, 2006.

[9] Gandhi, M. "Cow urine: It can be used as both pesticide and bio fertilizer" People for animals India's largest animal welfare organization, India, 2013.

[10] Bristow, A.W., Whitehead, D.C., Cockburn, J.E. Nitrogenous constituents in the urine of cattle, sheep and goats. J Sci Food Agri., vol.59, pp. 387-394, 2006

[11] Mostafa, M., Jahan, I.A., Riaz, M., Hossain, H., Nimmi, I., Miah, A.S., Chowdhury, J.U. Comprehensive analysis of the composition of seed cake and its fatty oil from Swietenia mahagoni Jacq. growing in Bangladesh. Dhaka Univ. J. Pharm. Sci., vol. 10, no.1, pp. 49-52, 2011.

[12] Walter, J.F. Commercial experience with neem products. Humana Press., pp.155-170, 1999.

[13] Karim, M.A. "Management of insect pests of vegetables" Proc.Workshop, AVRDC, BARC, Dhaka. pp.56-59, 1995.

Publish your research article in AIJR journals-

$\checkmark$ Online Submission and Tracking

$\checkmark$ Peer-Reviewed

$\checkmark$ Rapid decision

$\checkmark$ Immediate Publication after acceptance

$\checkmark$ Articles freely available online

$\checkmark \quad$ Retain full copyright of your article.

Submit your article at journals.aijr.in 